\title{
Analysis on the Difficulties in College Oral French Teaching and the Cultivation of the Communicative Competence
}

\author{
Li Yang \\ Xi'an International University, Xi'an, Shaanxi, 710077
}

Keywords: college oral French teaching; difficulties; communicative competence

\begin{abstract}
In the actual international trade, to use the language of the client could achieve a satisfied communication result; it also could reach a satisfactory communication achievement. But, students often feel difficulty in learning and application of foreign language, especially when they have not deeply understand the foreign language culture, a lot of communication misunderstandings which could influence the communication objective would occur. If these misunderstandings occur in the trade activities, it may bring a lot of obstacles to the smooth development of trade. Therefore, it is necessary to pay more attention to the learning of relevant communication skills and the summarization of relevant experience, at the some time, to enhance the students' understanding and mastery of foreign culture, so as to enhance students’ ability of language application.
\end{abstract}

As the rapid development of economic globalization, the exchanges between China and France-speaking countries are more in-depth in a many fields; this makes the demand for talents who master French increase, and puts forward new requirement for oral communication ability of these talents. In this way, during the process of French teaching in Chinese colleges and universities, the training target of students' oral communication ability would be higher, and the French teaching would be more difficulty than any time before. For the teaching and learning of a foreign language, it is mainly reflected in four aspects: listening, speaking, reading, and writing, while speaking is one of the most important parts, and it could not only reflect the students' grammar application ability, but also their ability of listening; furthermore, it reflect students' overall ability of French. For the most college students, their listening and speaking ability is weaker than reading and writing ability, and it is very regrettable that the traditional teaching model does not emphasize the cultivation of students' listening and speaking ability, which leads to the "mute" situation of foreign language talents in China.

\section{The Importance of Oral French Teaching and Learning}

Nowadays, it is a modern society with economic globalization as its background; the economic and political exchanges between different countries become more and more. French is an important working language of European Union and some international organizations such as the United Nations; its using scope is very extensive, so it is very significant to strengthen the French teaching and learning for promoting the international economic and political exchange. French-speaking populations are widely spread around the world, mainly in European and African countries; as the prosperous economic exchanges between China and these countries, the talents who master French could process more working opportunities naturally. The cultivation of translator now is the key teaching direction of the universities; French has naturally become one of the most important foreign languages in the universities. In diplomatic translation, simultaneous interpretation is the highest level of translation, but the lack of talents in this field makes the difficult of oral expression obvious in French learning. According to the College French Syllabus, the student whose major is French must have strong reading ability and a certain level of listening, speaking, writing and translating ability. This shows that there are some differences and requirements between the output (speaking and writing) ability and input (listening and reading) ability in the French education. In the modern life, the network technology develops very quickly and the relevant materials about French studying become richer and richer, the input materials and output materials also become 
richer than before, this provides more overall support for the study of French major students ${ }^{[1]}$.

\section{Analysis on the Difficulties in Oral French Teaching}

In the traditional teaching model of French, the content of courses is mainly related to how to cultivate the students' reading and writing ability instead of how to cultivate the students' overall language ability, the teachers spend most of time in class on teaching the theoretical knowledge but leave little time for the listening and oral cultivation. What's more, even though the teachers have some French questions in the classroom for the students to answer, most students can only use a simplex and mechanical way to answer the questions, and some of them need to follow the original textbook to do so. It can be seen that these French learners are not good at using French to communicate with the others.

For the most Chinese students who learn a foreign language, they have little opportunity to using the foreign language, so they are weak in the application of the language. When the students who learn French communicate with the others in French, some of them would feel difficulty to speak French correctly and fluently so that they are unwilling or afraid to speak French. Moreover, most of the Chinese students are introversive and shy, and they could not communicate with others in French bravely if it is not very necessary, so their application flexibility of oral French is weak ${ }^{[2]}$.

The poor language application circumstance also is one of the predicaments of the university oral French teaching. In the French class of many universities, the teachers could only speak French when they teach the sophomores and the students who are the higher grade, but one third language of the teacher in class is still the mother tongue of the students, these would heavily obstacle the students' learning of oral skills and the enhancement of their expression ability. In addition, the number of foreign French teacher in universities of China is relatively few, so the language application circumstance is relatively poor, this makes the students could not exercise their oral French skills and improve their French ability in class and after class.

\section{The Strategies of Cultivating the Communicative Competence of College Students}

As the deep exchanges between China and the European and African countries in economic and political fields, we find out that the talents who have a good command of oral French is insufficient. So it is necessary to strengthen the students' cultivation of mastering oral French, so as to strengthen the exchange between China and other countries, and to promote the countries to development harmoniously and together. Therefore, in the university French teaching, in order to improve the teaching efficiency, the teachers should not only strengthen the cultivation of the students' elementary knowledge, but also enrich the teaching content and method of teaching, at the some time, provide the good language circumstance for the students, so as to promote the students' oral French ability.

Enthusiasm is a key factor that influences the communication of the students who speak French, in the university French teaching, the teachers should inspire and cultivate the subject consciousness of the students, promote the students to join into the class activities actively, and encourage the student to try to speak French bravely ${ }^{[3]}$. Moreover, the teachers should give full play to their leading and guiding role, develop scientific teaching models and methods according to the actual teaching conditions, adopt the fundamental principle of teaching, i.e., teaching different students according to their aptitudes, and continuously improve the students' communicative competence in French. At last, the teachers should adopt the scientific and reasonable evaluation system, give affirmation and support to the students' oral communicative competence in class and after class, and improve their confidence in communication in oral French constantly, so as to inspire the students to communicate with the others bravely in French.

Because of lacking the cultural background of the communication object, a lot of communication misunderstanding would be occurred. So, in the teaching of oral French, it is necessary to cultivate the students' multicultural background. No matter in class or after class, should the teachers not only teach the application skill and studying skill of French, but also lead the students to read and 
understand the French culture, so as to lay a solid foundation for the oral French application of the students. For example, to guide the students to understand the customs, religious ideas, values and daily life habits of French-speaking countries. These factors may be widely used in practical French communication, and can also enhance the students' skills in learning French ${ }^{[4]}$. What's more, the students need to have a comprehensive and detailed understanding of the cultural background of French-speaking countries in order to reduce linguistic errors in practical communication and show the respects to the participators of communication.

French teaching should not leave life, but should be based on life, because life is an important source of language. So, the French teaching must be close to the actual life, the teachers should adopt the proper teaching materials for the teaching of oral French according to the actual life, so as to achieve a successful communication for the communicators. What's more, the teaching process should also apply the advanced teaching ideology and teaching model scientifically, break through the shackles of traditional teaching models, optimize the students' learning circumstance and enable the students to have more opportunities for speaking French. While enriching students' practical experience, at the some time, the teachers should make a reasonable assessment and evaluation of the shortcomings of the students' communicative competence in French, so as to improve their competence $^{[5]}$. In the choice of oral French teaching materials, the teachers should choose more materials that are easy to understand and that are closed to life, and the students could also enrich the students' understanding of French by reading a lot of other French materials. In the process of reading materials, the students should not only think and explore independently, but also practice oral communication in French with their classmates, and explain their views and ideas in French, so as to improve their oral French ability.

In the process of communication in oral French, it is not only the output (speaking) of French but also the input (listening) of French, and listening is very important. Only when the output and input are in harmony with each other, can the communication in French be carried out effectively. So to speak, in the teaching of oral French, the teachers should harmoniously improve the students' listening and oral expression ability, and combine the two into a systematic entirety, and then put it into practice, so as to improve the students' communicative competence in French ${ }^{[6]}$. The course of oral French in university is limited, at the some time, the opportunities for the students to practice their listening ability is also limited, so the students should practice their listening ability actively after class. For example, watching French movies, listening to French news, radio, songs and so on, and these all can improve the students' French listening ability to some extent. Furthermore, in order to correct the students' oral mistakes, the teachers should correct their students mistakes during the process of the communication, and teach them the key knowledge that is related to their mistakes; although this approach would influence the students' confidence in learning French, but the teachers could also promote students' enthusiasm by affirming the students' advantages in French communication.

Generally speaking, the French ability of the lower grade students is lower than that of the higher grade students, so the teachers could carry out the teaching according to the students' actual French level in the actual teaching activities and improve the students' French ability step by step, so as to encourage the senior students to improve their oral English ability actively and autonomously. Besides above, the teachers should encourage the students of lower grade to communicate with the senior students in French, to the contrary, encourage the senior students to help the lower students to learn French actively, so as to achieve the common progress. Furthermore, the teachers should actively organize some French speaking competitions, recitation competitions, drama competitions, simulation communication competitions and so on, so that the students can improve their oral French ability by more communication opportunities and platforms.

\section{References}

[1] Zheng Liming. Application of Cultural Introduction in the Teaching of French as the Second Foreign Language[J]. Industrial \& Science Tribune, 2017, 04: 160-161. 
[2] Zheng Fangyuan, Discussion on the Difficulties of Oral French Teaching in Colleges and Universities and the Cultivation of Communicative Competence[J]. Modern Communication, 2.17, 01: 133.

[3] Shu Qing, Analysis on Several Methods on Teaching of the Second Foreign Language[J]. Science \& Technology Vision, 2017, 05: 186.

[4] Ning Wenli, Research on the Reformation of French Course for the Cultivation of the Practical Talent[J]. Journal of Jiamusi Vocational Institute, 2017, 02: 339-340.

[5] Zhou Ling, Zhang Shanshan, Liu Yuan, etc. The Application of Communicative Teaching Method in Elementary Oral French Class[J]. Ability and Wisdom, 2017, 34: 178-179.

[6] Wang Ying, Discussion on the Oral Language Teaching at the Elementary Stage of College French----Taking the Oral Course of the Sophomore Whose Major is French[J]. Ability and Wisdom, 2018, 02: 83-84. 